\title{
Influence of AlSi7Mg0.3 Alloy Modification on Corrosion Behaviour in the Salt Environment
}

\author{
Sylvia Kusmierczak, Iryna Hren
}

Faculty of Mechanical Engineering, J. E. Purkyne University in Usti nad Labem. Pasteurova 3334/7, 400 01 Usti nad Labem. Czech Republic. E-mail: sylvia.kusmierczak@ujep.cz, iryna.hren@ujep.cz

In the case of eutectic and hypoeutectic silumins, the modification is carried out on molten metal prior to casting with strontium, which has a limited modification effect of max. 1 - 1.5 hours. The aim of the realized experiment is to investigate the microstructure change and corrosion evaluation of the AISi7Mg0.3 aluminium alloy in combination with the strontium modifier. AlSi7Mg0.3 alloy was used for the experiment using $0.04 \%$ strontium modifier and $0.15 \%$ beryllium was added to prolong the time effect of the strontium modification. Beryllium was used as an AlBe5 master alloy and the samples were cast by gravity casting into a metal preheated mold. Chemical composition analysis was performed by spectral analysis and microstructure was evaluated by light microscopy. Alloys formed without and after the addition of the modifier were subjected to a corrosion test followed by evaluation of the initial microstructure.

Keywords: aluminum alloys, modification, microstructure, corrosion test

\section{Introduction}

Metal corrosion is one of the methods of physicochemical interaction of the metal and the environment, leading to changes in the properties of the metal, which may cause significant impairment of the function of the metal $[1,2]$. The corrosion test is carried out with the use of a device called the corrosion chamber, which best describes the corrosion environment in which the test materials are working. Corrosion affects all types of materials, their reactions with the environment. Also, the environment that causes corrosion, is very diverse. The most widely used corrosive environment is atmospheric corrosion, which sustained the action is exposed to the bulk of the products. Also, other environments are technically significant, especially different soil, in which are stored equipment, natural water, like the waters of the river and especially the sea, which acts aggressively to vessels, port and dam equipment, automobiles, aircraft, etc [3]. Great importance has the process of corrosion degradation even in the automotive industry, as it leads to great financial losses. One area of research in this sector is the use of aluminium alloys in the context of corrosion of loading, to which the cars are exhibited in their normal operation.

The subject of the article is the alloy on the base of the AlSi7Mg, which and has been developed for the automotive industry on the soil on the Faculty of Mechanical Engineering. Master alloy AlSi7 was alloyed with $\mathrm{Mg}$ and subsequently modified $\mathrm{Sr}$ and $\mathrm{Be}$, to soften the structure of the starting alloy and to reach higher values of elongation and strength and at the same time improve the technological properties, specifically castability and machinability.

Zhu [4] in their work studied the effects of heat-processed on the microstructure and behaviour of corrosion of the joint of aluminium alloy AA2219 after welding method TIG with variable polarity. The experiment was verified that during welding the maximum temperature in the $\mathrm{HAZ}$ varies from $490^{\circ} \mathrm{C}$ to $548^{\circ} \mathrm{C}$, which led to the dissolution of the subtle phases of $\mathrm{A} 12 \mathrm{Cu}$ and segregation along the grain boundaries. The result of the research was that the implementation of PWHT was the microstructure of the weld metal more homogeneous, the tensile strength was increased by $44 \%$ and the efficiency of connections reached $76 \%$. Huang [5] in his article dealt with the influence of homogenization on the corrosion behaviour of aluminium plates 5083-H321. The fact is that, compared with fine-grained microstructure should strongly elongated grains impede the penetration perpendicular to the principal direction of deformation because most of the grain boundaries would prevent deeper penetration of the corrosion. The results showed that the samples which were not homogenized, exhibit increased resistance to corrosion than the homogenized samples. Li [6] focused on the corrosion behaviour and mechanical properties of aluminium alloy $\mathrm{Al}-\mathrm{Zn}-\mathrm{Mg}$. The amount of secondary phases in the weld causes the formation of galvanic corrosion. In their work showed that the mechanical properties of the welded joints are lower than the properties of the base metals. Donatus [7] in his scholarly work examined the spread of corrosion products in aluminium alloys. Their work showed that the method of spread of corrosion in alloys is significantly different due to the presence of phase $\mathrm{Al} 3 \mathrm{Mg} 2(\beta)$. Öztürk et. al. [8] investigated 120,170 and $250 \mathrm{ppm} \mathrm{Sr}$ addition on a356 android alloy and found that $120 \mathrm{ppm} \mathrm{Sr}$ in die-cast a356 android alloy resulted in the highest corrosion resistance and the lowest corrosion rate compared to the unmodified alloy, as a result of the growth of the protective oxide layer would $\mathrm{Sr}$ addition. Moustafa [9] in his scientific work focused on the influence of additions of $\mathrm{Mg}$ and $\mathrm{Cu}$ on the microstructural characteristics and tensile properties of the eutectic alloys Al-Si modified Sr. The fact is that copper forms the other secondary phase with $\mathrm{Al}$, which is precipitated during solidification, either as a block $\mathrm{Al} 2 \mathrm{Cu}$ or in the eutectic form as $(\mathrm{Al}+\mathrm{Al} 2 \mathrm{Cu})$. The results show that the addition of $\mathrm{Mg}$ reduces the fluidity and eutectic temperature Si. Liao et al. [10] investigated the corrosion resistance of $\mathrm{Sr}$ modified near-eutectic Al-Si alloy and found that $\mathrm{Sr}$ addition decreased the corrosion resistance compared to unmodified alloy at longer immersion times. Hren [11] in their work investigated the extension of the 
modification effect in hypoeutectic silumin modified by strontium. The result was that the most optimal time to effect modification of the effect after the addition of beryllium is 3 hours. Salt fog corrosion test is a method that is a very important aspect of obtaining information on the corrosion resistance of materials in an experimental form. The literature does not provide information on the action and course of corrosion attack on aluminium alloys after their prolonged modification in the salt environment. Therefore, the paper aims to investigate and analyse the effect of $\mathrm{AlSi} 7 \mathrm{Mg} 0.3$ alloy modification on its corrosion behaviour in the salt environment using light microscopy methods. The corrosion resistance of aluminium alloys can only be improved with a detailed understanding of all factors affecting the microstructure of hypoeutectic silumin.

\section{Experiment}

Tab. 1 Chemical composition of AlSi7Mg0,3 alloy
AlSi7Mg0,3 alloy (EN 1706-98) was added for the experiment with the addition of the $\mathrm{Sr}$ modifier and AlBe5 master alloy. This material contains $92.7 \%$ aluminium, $7 \% \mathrm{Si}$ and $0.3 \% \mathrm{Mg}$ respectively (chemical composition of the alloy - Table 1). The next step was the addition of the $\mathrm{Sr}$ modifier and the Be addition was used to prolong its performance. In this case, $\mathrm{Sr}$ is used as an AlSr10 master alloy with the addition of a $0.04 \%$ modifier. Beryllium is also added as a master alloy of AlBe5 at a concentration of $0.15 \%$. To verify if the modifications were prolonged, samples were cast after each hour up to 4 hours after the addition of $\mathrm{Sr}$ and Be. Melting was carried out at (750-760) ${ }^{\circ} \mathrm{C}$ and by gravity casting into a preheated metal mold (at $200^{\circ} \mathrm{C}$ ) the samples were cast and then left in the mold until they cooled. The resulting castings had a cylinder shape of approximately $19 \mathrm{~mm}$ in diameter and $210 \mathrm{~mm}$ in length and became the basis for experimental samples.

\begin{tabular}{|c|c|c|c|c|c|c|c|c|c|}
\hline \multicolumn{10}{|c|}{ Chemical compostion [wt. \%] } \\
\hline $\mathbf{S i}$ & $\mathbf{F e}$ & $\mathbf{C u}$ & $\mathbf{M n}$ & $\mathbf{M g}$ & $\mathbf{C r}$ & $\mathbf{Z n}$ & $\mathbf{P b}$ & $\mathbf{T i}$ & $\mathbf{A l}$ \\
\hline $6.5-7.5$ & 0.17 & 0.05 & 0.1 & $0.25-0.45$ & - & 0.07 & - & $0.08-0.025$ & residue \\
\hline
\end{tabular}

\section{Microscopic evaluation of structure and quality of modification}

The Olympus Lext OLS 3100 confocal microscope was used to evaluate the microstructure. The microstructure of the $\mathrm{AlSi} 7 \mathrm{Mg} 0.3$ alloy is shown in Figure 1 and is typically hypoeutectic silumin. As indicated [7], the microstructure of the sample consists of $\alpha$ dendritic cells and a eutectic consisting of particles of eutectic silicon and $\alpha$ solid solution.

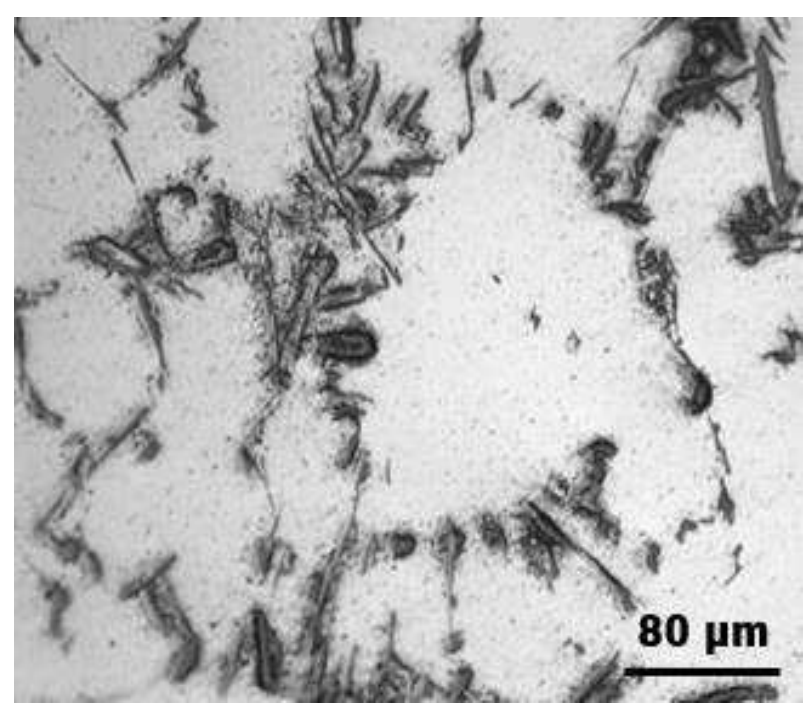

Fig. 1 Microstructure of AlSi7Mg0.3 alloy

Another experimental sample was $\mathrm{AlSi} 7 \mathrm{Mg} 0.3$ alloy modified with $\mathrm{Sr}$ and $\mathrm{Be}$. This sample was chosen based on the results obtained in [11], where the most significant change in microstructure occurs after 3 hours of modification.

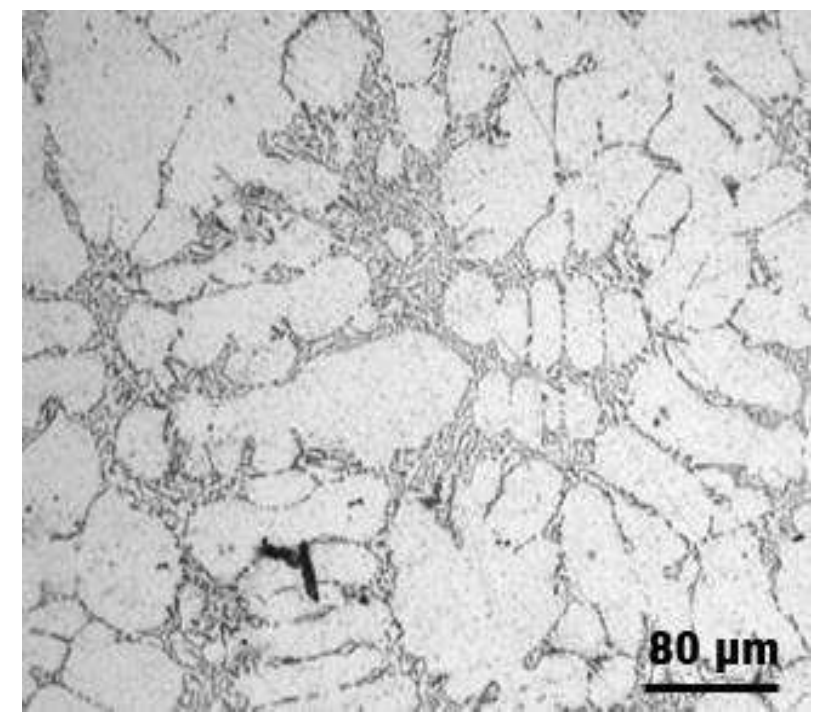

Fig. 2 Microstructure of AlSi7MgO.3 alloy modified by $\mathrm{Sr}$ and $\mathrm{Be}$

In Fig. 2, the optimum effect of the modification is evident, where the deposited eutectic silicon has a perfect round or slightly elongated shape.

\section{Microscopic analysis after corrosion loading}

The samples were exposed to corrosion in the corrosion chamber according to ČSN EN ISO 9227. The test was carried out with graduated exposure times of 96,168 , 240, 480, 720 and 1008 hours. The cycles were run in a test environment of $5 \% \mathrm{NaCl}, 50 \mathrm{~g} / \mathrm{L}$, at $350^{\circ} \mathrm{C} \pm 20^{\circ}$ $\mathrm{C} \mathrm{pH}$ of the accumulated solution 6.5 to 7.2.

Exposure time and sample designation are given in Table 2 . 
Tab. 2 Exposure time and labelling of samples

\begin{tabular}{|c|c|c|c|c|c|c|}
\hline \multirow{2}{*}{ Material } & after & after & after & after & after & after \\
& $\mathbf{9 6 h}$ & $\mathbf{1 6 8 h}$ & $\mathbf{2 4 0 h}$ & $\mathbf{4 8 0 h}$ & $\mathbf{7 2 0 h}$ & $\mathbf{1 0 0 8 h}$ \\
\hline \multirow{2}{*}{ AlSi7Mg0.3 } & Sample & Sample & Sample & Sample & Sample & Sample \\
& $1-1$ & $1-2$ & $1-3$ & $1-4$ & $1-5$ & $1-6$ \\
\hline \multirow{2}{*}{ AlSi7Mg0.3+AISr10+AIBe5 } & Sample & Sample & Sample & Sample & Sample & Sample \\
& $2-1$ & $2-2$ & $2-3$ & $2-4$ & $2-5$ & $2-6$ \\
\hline
\end{tabular}

After completion of the corrosion test, samples were taken for corrosion attack evaluation. The resulting microstructures are shown in Figure 3.

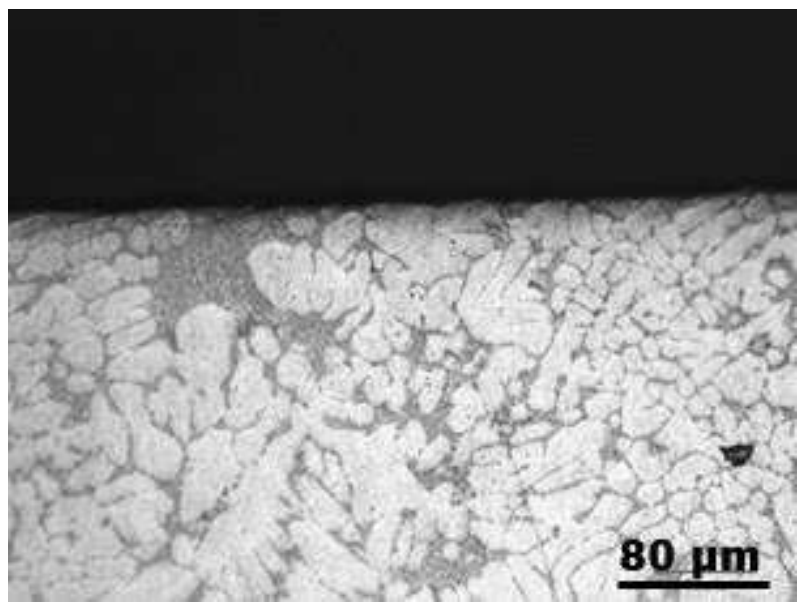

a) AlSi7Mg0.3 alloy

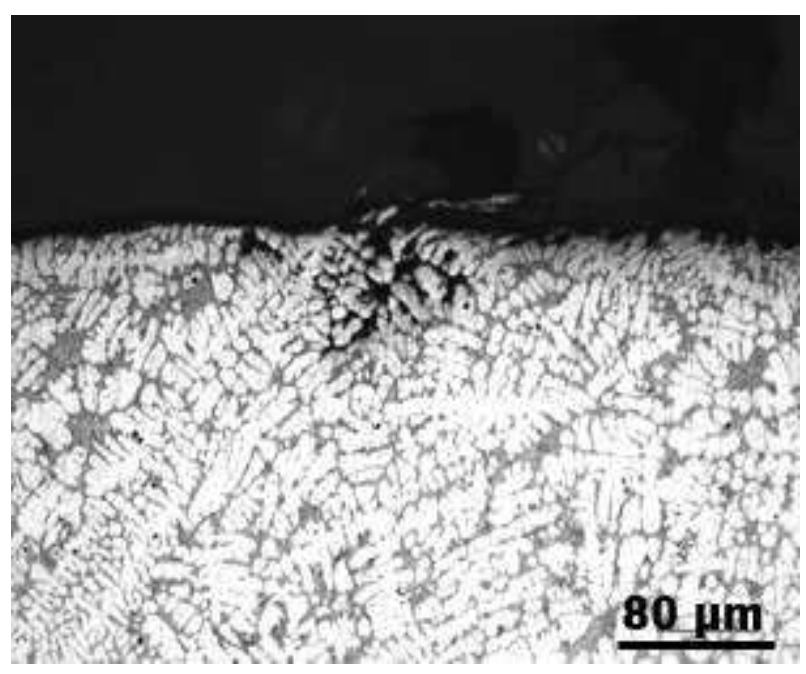

b) $\mathrm{AlSi} 7 \mathrm{Mg} 0.3+\mathrm{AlSr} 10+\mathrm{Be}$ alloy

Fig. 3 Microstructure after 96 h loading

In Figure $3 \mathrm{a}$ it can be seen that the unmodified AlSi7Mg0.3 alloy retains a continuous passivation layer of $\mathrm{Al}_{2} \mathrm{O}_{3}$, which prevents corrosion penetration into the material. In the sample after modification, Fig. 3b, there is an apparent break in the cohesiveness of the material due to interdendritic porosity, which is related to the course of crystallization of the material. In this area, the formation of corrosion products in intercrystalline spaces followed - intercrystalline corrosion.

Fig. 4 a, b show an uneven pitting of corrosion, it can be seen that the modified AlSi7Mg0.3 alloy shows more corrosion attack.

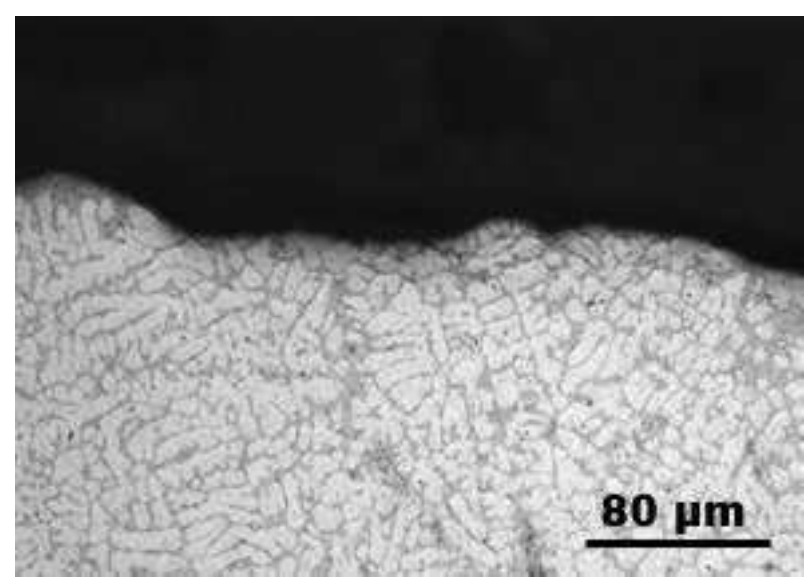

a) AlSi7Mg0.3 alloy

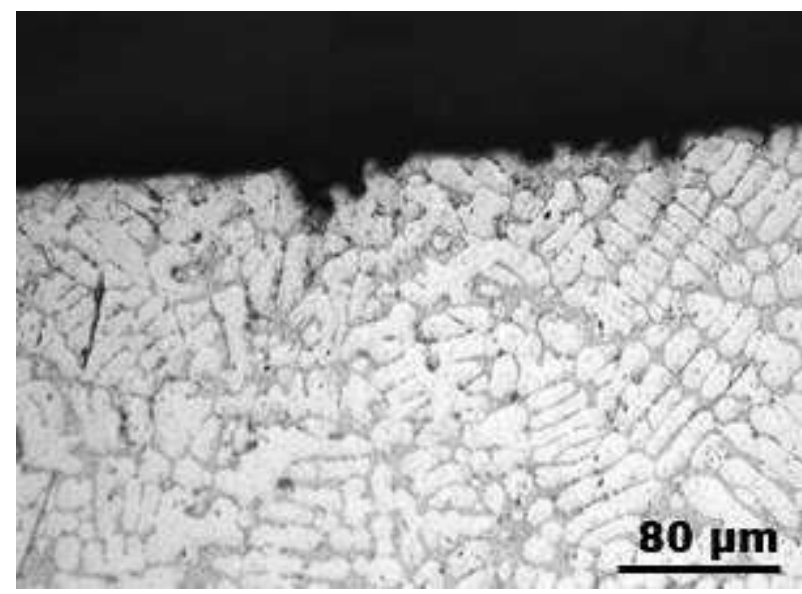

b) AlSi7MgO $3+A l S r 10+$ Be alloy

Fig. 4 Microstructure after 240 h loading

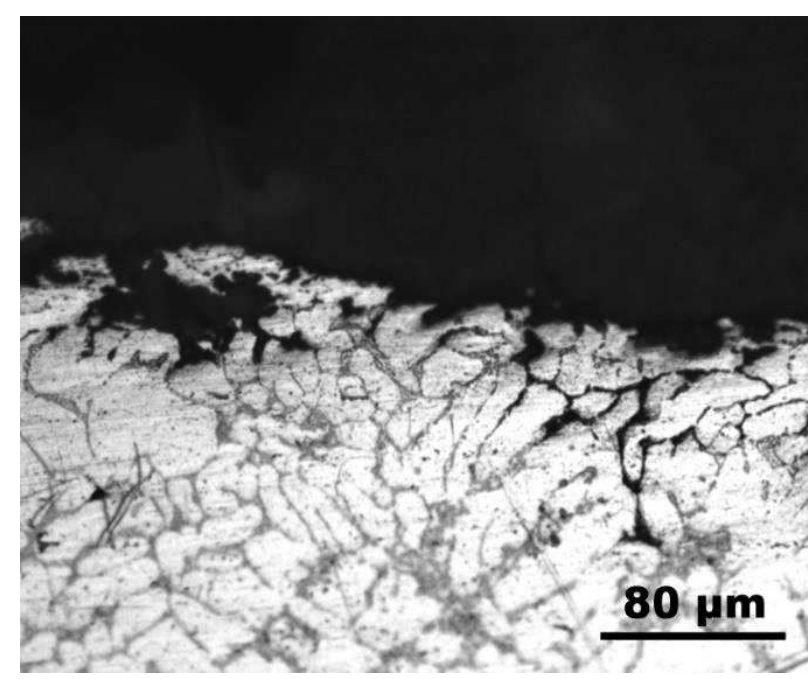

a) AlSi7Mg0.3 alloy 


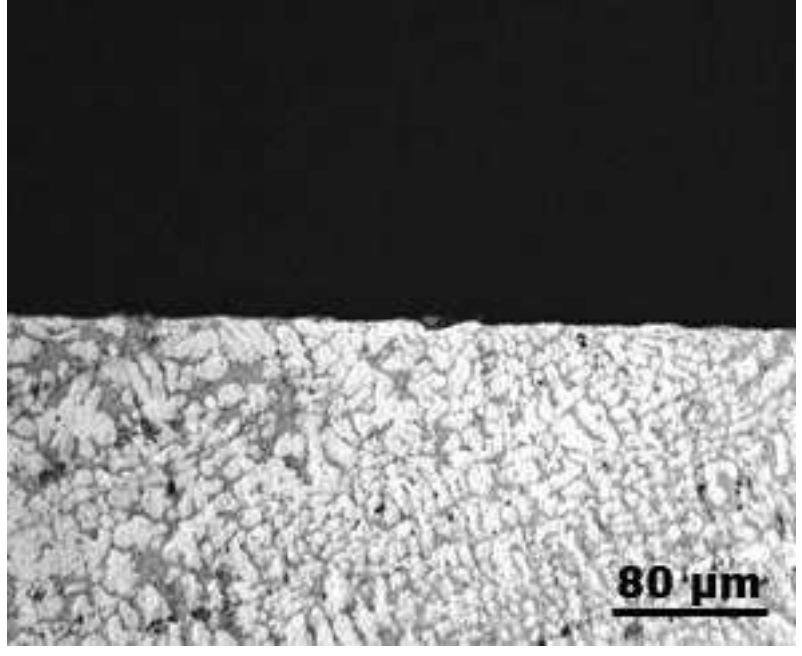

b) AlSi7MgO.3+AlSr $10+$ Be alloy

Fig. 5 Microstructure after 480 h loading

AlSi7Mg0.3 alloy was selected for further evaluation before and after modification, after 480 hours loading in corrosion chamber. As shown in Fig. 5a, interdendritic porosity occurred in the material, which probably affected interdendritic corrosion. Conversely, the alloy shown in Figure $5 \mathrm{~b}$ shows the retention of the $\mathrm{Al}_{2} \mathrm{O}_{3}$ passivation layer. This phenomenon may be caused by the influence of the modifier on individual phases of the microstructure of the analysed material.

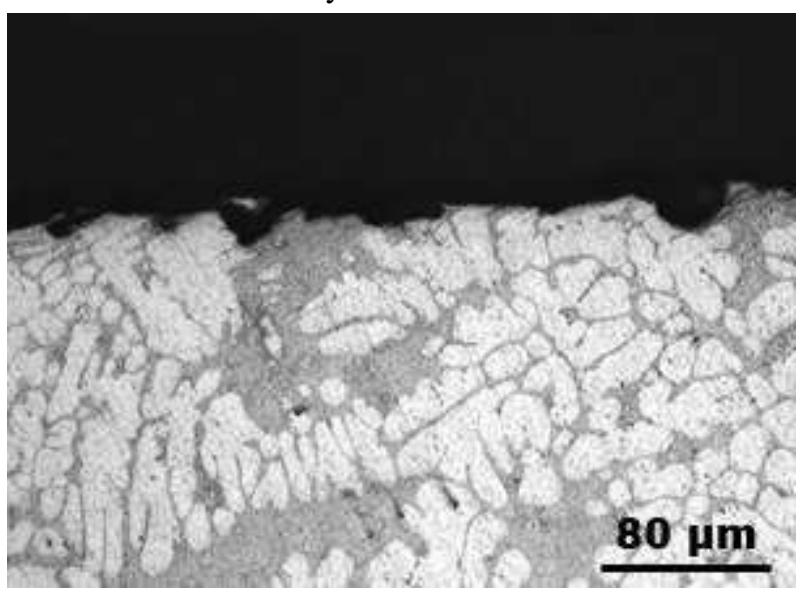

a) AlSi7Mg0.3 alloy

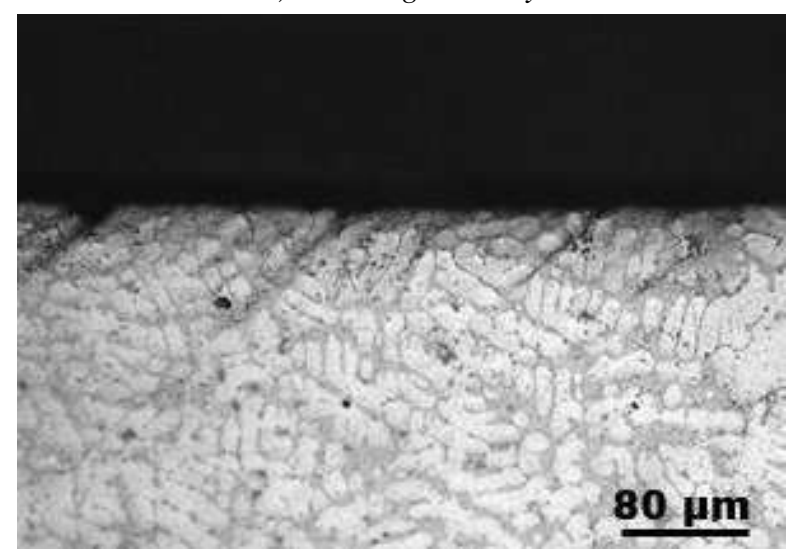

b) AlSi7Mg0.3+AlSr10+Be alloy

Fig. 6 Microstructure after 720 h loading
Figures 6 show unevenly distributed pitting corrosion, and it can be seen that the corrosion attack after 720 hours of load on the modified alloy is only slightly apparent. As with the previous sample, it was confirmed that the addition of the modifier makes the alloy more resistant to corrosion.

\section{Discussion of results}

Sample 1 is $\mathrm{AlSi} 7 \mathrm{Mg} 0.3$ alloy - individual samples show uneven corrosion attack by pitting. This attack deepens with longer exposure time in a neutral corrosion fog of $5 \% \mathrm{NaCl}$. Due to the low number of corrosion attacks on the surface of sample 2, which does not increase significantly due to the exposure duration in the neutral corrosion fog of $5 \% \mathrm{NaCl}$ solution, it can be concluded that a uniform oxide layer of $\mathrm{Al}_{2} \mathrm{O}_{3}$ is formed on the surface.

In sample 2, after 96 hours of exposure, material interruption due to interdendritic porosity was observed, which was reflected in the occurrence of intergranular corrosion. This caused a surface defect to affect the formation of the oxide layer, thereby affecting the entire corrosion behaviour of the surface of the material. After another period of exposure, up to 720 hours, we can see pitting corrosion, which this time appears to be even.

The results of the experiment show that the AlSi7Mg0.3 alloy after three hours modification of AlSr $10+$ AlBe 5 could be more resistant to corrosion attack in salt mist. In general, and experiments have confirmed that magnesium in AlSi7Mg0.3 alloy and modifiers based on $\mathrm{Sr}$ and Be have a great influence on the corrosion behaviour of the alloy in the neutral corrosion fog of $5 \% \mathrm{NaCl}$ solution - pitting increases and the overall corrosion behaviour of the alloy is affected and there are other forms of corrosion attack.

\section{Conclusion}

Experimental samples were made and cast in the unmodified and modified state. The chemical composition of the samples was analysed using a Q4 TASMAN optical emission spectrometer. Microscopic observation was performed on an Olympus LEXT OLS 3100 confocal microscope.

AlSi7Mg0.3 alloy has been identified as a pitting type of corrosion. Compared to the previous sample, results from AlSi7Mg0.3 alloy with modifier showed that crystallization method and microstructure quality affect the process of formation of corrosion products, leading to the occurrence of intergranular corrosion. The occurrence of intergranular corrosion may be related to the effect of the modification on the microstructure of the alloy and the presence of yet unidentified phases related to the modification process. Methods of light microscopy do not allow to identify the elemental composition of individual intermetallic phases of the alloy, which are evident especially in modified alloys in the images. Therefore, there is a recommendation to perform EDS analysis to detect elements in intermetallic phases. This measurement could illuminate the behaviour of the $\mathrm{AlSi} 7 \mathrm{Mg} 0.3$ alloy in the corrosive environment of salt mist. 
In conclusion, the corrosion degradation of aluminium alloys is mainly influenced by their chemical composition. The authors' claim $[4,6]$ that the modification of aluminium alloys has a positive effect on increasing the corrosion resistance was also confirmed.

\section{Acknowledgements}

This contribution came from support of project $S G$ 4820715 2014-48 01 at UJEP.

This contribution came from support of project $S G$ 4820715 2023-48 01at UJEP.

\section{References}

[1] KUSMIC, D., VAN, D. T., HRUBY, V. (2018) Corrosion and Wear Resistance of Plasma Nitrided and Duplex Treated 42CrMo4 Steel. Manufacturing Technology, Vol, 18, No. 2, pp. 259-265.

[2] DVORSKY, D., KUBASEK, J., VOJTECH, D. (2017) Corrosion Protection of WE43 Magnesium Alloy by Fluoride Conversion Coating. Manufacturing Technology, Volume 17, No. 4, pp. 440446.

[3] KALINCOVÁ, D., ŤAVODOVÁ, M., KUŚMIERCZAK, S. (2017). Analysis of the Properties Aluminium Casting Motorcycle Forks Arm after Compression Test. Manufacturing Technology, Volume 17, No. 5, pp. 717-722.

[4] ZHU, Z. Y., DENG, C. Y., WANG, Y., YANG, Z. W., DING, J. K., WANG, D. P. (2015). Effect of post weld heat treatment on the microstructure and corrosion behavior of AA2219 aluminum alloy joints welded by variable polarity tungsten inert gas welding, Materials \& Design, Vol. 65, pp. 1075-1082.

[5] HUANG, Y., LI, Y., XIAO, Z., LIU,Y., HUANG, Y., REN, X. (2016). Effect of homogenization on the corrosion behavior of 5083-H321 aluminum alloy. Journal of Alloys and Compounds, Vol. 673, pp. 73-79.

[6] LI, S., DONG, X., SHI, L., LI, P., YE, F. (2017). Corrosion behavior and mechanical properties of $\mathrm{Al}-\mathrm{Zn}-\mathrm{Mg}$ aluminum alloy weld. Corrosion Science, Vol. 123, pp. 243-255.

[7] DONATUS, U., THOMPSON, G. E., OMOTOYINBO, J. A., ALANEME, K. K., ARIBO, S. AGBABIAKA, O. G. (2017). Corrosion pathways in aluminium alloys. Transactions of Nonferrous Metals Society of China, Vol. 27, pp. 55-62.

[8] ÖZTÜRK, G. HAPÇI, A., ERZI, E., DISPINAR, D., ORHAN G. (2018). Effects of strontium addition on the microstructure and corrosion behavior of A356 aluminum alloy. Alloy. Comp., Vol. 763, pp. 384-391.

[9] MOUSTAFA, M. A., SAMUEL, F. H., DOTTY, H. W., VALTIERRA, S. (2002). Effect of Mg and $\mathrm{Cu}$ on the microstructural characteristics and tensile properties of Sr-modified $\mathrm{Al}-\mathrm{Si}$ eutectic alloys. Cast Metals Res, Vol. 14, pp. 235-253

[10] LIAO, H., DONG, G., SUN, G. (2007). Investigation on influence of sodium- or strontium-modification on corrosion-resistance of $\mathrm{Al}-11.7 \% \mathrm{Si}$ alloy. Material Science, Vol. 42, pp. 5175-5181.

[11] HREN, I., MICHNA, Š., DROZDYK, L., CAIS, J., MICHNOVÁ, L., SVOBODOVA, J., HODINÁŘ, L. (2018). Research of the Influence on the Modification of Beryllium in Al-Si Alloy. Metallofiz. Noveishie Tekhnol., Vol. 40, No. 12, pp. $1637-1647$.

[12] KUŚMIERCZAK, S., MAJZNER, T. (2016). Analysis of The Causes the Degradation of Part Steam Generator by Using Microscopy Methods. Manufacturing Technology, Vol. 16, No. 5, pp. 995-998. 